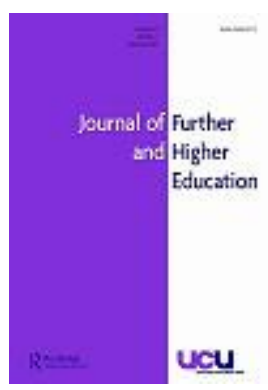

\title{
Support from Extended Family in Higher Education: A
} Narrative Literature Review

\begin{tabular}{|r|l|}
\hline Journal: & Journal of Further and Higher Education \\
\hline Manuscript ID & CJFH-2018-0277.R1 \\
\hline Manuscript Type: & Original Paper \\
\hline Keywords: & social support, extended family, diversity, higher education \\
\hline \multicolumn{2}{|l}{} \\
\end{tabular}

\section{SCHOLARONE ${ }^{m}$ \\ Manuscripts}




\title{
Support from Extended Family in Higher Education: A Narrative Literature Review
}

\begin{abstract}
Although the support provided by extended family (EF) members to university students has recently been more investigated, EF support in Higher Education (HE) is rarely considered as an element worthy of analysis in its own right. Situated in an international context and looking across diverse HE systems, this narrative review has two main aims. First, to provide a map of research on the influence of EF members in HE. Second, to link research to HE practitioners and policy makers as a way to promote diversity within universities. The main argument is that by considering students' networks of support outside university, more effective diversity policies can be implemented at the institutional level. Employing the concepts of extended family, funds of knowledge and social support (SS) as a foundational background, the paper identifies SS that achieves positive outcomes and support which outcomes are less effective. Fifty-three studies employing different methodologies were considered. Selected articles (22) were then classified, synthesised and analysed by the author. The paper discusses the role of EF in HE in relation to four sub-groups of students: traditional; non-traditional; international and dropout. Four main constants were identified in the literature: a) SS is a cultural-based practice; b) research emphasises positive effects of SS; c) research tends to focus on ethnic minorities, and d) there is an unclear separation between parental and the support provided by EF members. The paper concludes with a discussion of the implications for further research and practice.
\end{abstract}

Keywords: social support; extended family; diversity, higher education. 


\section{Support from Extended Family in Higher Education: A Narrative Literature Review}

\section{Introduction}

Socio-biologists have demonstrated that, in addition to a traditional nuclear family, young people live in a wide variety of social structures. However, research on cooperative rearing arrangements (in which group members other than parents are allowed to care for offspring) is rare (Hrdy, 2009), particularly in Western educational research. While parental involvement has been widely investigated, little is known about the role of the extended family (EF) in education and particularly regarding student participation in higher education (HE). A review on the economics of EF and kinship networks and their contribution to societies (Cox and Fafchamps, 2007) demonstrates that help from EF networks, particularly in developing economies, affects the distribution of economic well-being, thus affecting public income redistribution.

In the context of increasing pressure on Western social welfare systems and HE budgets, understanding the role of the EF is important, although, unlike the role of nuclear family arrangements, it has been largely absent from public debate (McGlone, Park, and Roberts, 1999). For example, UK studies on the kinship relationship (e.g. Broad, 2004; Grundy, Murphy and Shelton, 1999; McRae, 1999; Mitchell, 2007) have not looked at its influence on HE participation, despite the inclusion of students from diverse backgrounds being a major priority for successive UK governments (Brooks, 2005; Gates, Coward and Byrom, 2007). In the context of high tuition fees in diverse HE systems around the world, investigating the influence of EF and the extent to which it provides emotional, financial and/or academic support for HE students is crucial. This knowledge could help HE practitioners and policy makers implement effective diversity policies that take into account students' support networks. This review is situated in an international context and looks across diverse systems of HE. Hence, the implications of this literature review are not tied to a particular national 
context. The research questions guiding this study are:

1. What is the role of EF support in higher education?

2. Does support from EF members vary across ethnicities?

3. Do different student-types in HE experience different kinds of social support?

4. What are the changes that Higher Education institutions (HEIs) need to make to take advantage of what is known about social support networks?

Research relating to HE access has generally focused on the impact of individual institutions, ethnicity and social class of prospective applicants and their attainment (Lasselle, Keir and Smith., 2009; Reay, David and Ball, 2005; Reay, Crozier and Clayton, 2009; Watt and Paterson, 1997). This research shows that, while low socio-economic groups and minority ethnic groups have lately had better access to HE (Basit and Tomlinson, 2012), they are still under-represented (Boliver, 2013; Croxford and Raffe, 2014). To cite just one example of the limited access of one of these underrepresented groups, 'only $10 \%$ of the most disadvantaged working-class white British males progress to HE' (Baars, Mulcahy and Bernardes, 2016: 7). Access initiatives such as summer schools to bridge the gap between university and students from non-traditional backgrounds acknowledge that most such students come from families with little or no experience of HE. However, research and policies have not considered the role that EF can play in supporting (or not supporting) the necessary transition (Briggs, Clark and Hall, 2012; MacDonald and Stratta, 2001; Watt and Paterson, 1997). Lasselle et al. (2009), for example, consider how students' attitudes toward university are affected by their family, peers, school environment and financial considerations, but make no mention of EF.

Given the nature of the research questions guiding this study, this is a narrative review as its purpose is not to evaluate specific interventions (Evans and Benefield, 2001). The present review has two aims. First, to provide a map of research and consider the role of EF in HE, as 
an element worthy of analysis in its own right. Second, to link research in the field to HE practitioners and policy makers (Hammersley, 2001). This is important because, in order to promote diversity in HE, it is critical to understand students' support networks across different cultural groups. Considering the role that EF members have on supporting (or not) participation in HE is a timely and necessary step towards achieving diversity. The saying that 'it takes a village to raise a child' begs the question whether it takes a community of others, in addition to parents, to enable students from diverse social backgrounds to access and progress in HE. Such 'village' would include non-parent family members within the home, such as siblings, aunts, uncles and grandparents, as well as a wide range of family members outside of the home.

The next two sections cover the concepts underpinning this review and its methodology. Afterwards, the paper analyses the role of EF in HE in relation to four sub-groups: traditional students; non-traditional students; international students and students who drop out from HE. Finally, the last two sections explore implications for future research and practice.

\section{Theoretical framework}

Three apparently unrelated concepts construct the theoretical framework for this literature review: extended family, funds of knowledge and social support. These concepts provide the basis on which the analysis of the support provided by EF members to different types of university students was undertaken. The classic sociological study by Young and Willmott (1957) on family and kinship in London shows that an absence of relatives is as influential as their presence, yet little is still known about their role in society overall. According to Duranton, Rodríguez-Pose and Sandall (2009: 25), the family - 'one of humanity's most basic forms of institution' - is under-investigated. From an economical perspective, they explain that the traditional assumption is that family structures, because of their small size, tend to have less impact than other social institutions such as the state, 
religion or the law although, according to them, families have an impact on wider economic development. Family structures impact upon individuals' well-being, as well as their educational, work and social environment. Research has shown that families also have a wider impact on the social and economic development of societies. Support from EF is based on mutual dependence and is a key adaptive strategy with a generally positive impact (attenuating disadvantage), although negative effects (accentuating disadvantage) have also been reported.

Pallock and Lamborn (2006) understand EF as the networks of relatives beyond the nuclear family who provide social, emotional, and instrumental support. Typically, these multigenerational networks facilitate adaptive behaviour and allow the sharing of resources, and are often organized around a dominant figure such as a grandmother.

The sharing of resources and mutual dependence characterising extended families connects directly with our second concept. Funds of knowledge refers to the historically accumulated and culturally developed bodies of knowledge, skills and resources available within families (Moll, Amanti, Neff and Gonzalez, 1992). Funds of knowledge takes into account the social contexts in which families are immersed and which are crucial for the functioning of individuals of non-dominant backgrounds (especially ethnic minorities and low socio-economic groups). Although families from all socioeconomic background possess funds of knowledge, Rios-Aguilar and Kiyama (2017: 18) explain that funds of knowledge 'are constructed inside an ongoing struggle for and against domination'. As such, funds of knowledge constitute a community resource that enhances social collaboration (Rios-Aguilar and Kiyama, 2017), which takes us to our third concept, that of social support. According to Shumaker and Brownell (1984: 13), social support is 'an exchange of resources between at least two individuals perceived by the provider or the recipient to be intended to enhance the well-being of the recipient.' Shumaker and Brownell (1984) identify conceptual gaps in 
relation to social support, but their main contribution lies in the idea that the actual effects of the support may be either positive, negative or neutral, contribution that this paper exemplifies in relation to EF support to university students. According to Shumaker and Brownell (1984), almost all measurement has relied on self-report by the person in question, thus, we know very little about the perceptions of providers an aspect also analysed in this literature review. Similar to Shumaker and Brownell, Schwarzer and Leppin (1991) standing from a health sciences approach, have also claimed that research into social support has dealt only with the recipient perspective, thus studies should consider the interaction between both recipients and providers over a longer period as the relationships forged amongst extended family members tend to be. Schwarzer and Leppin (1991) also argue that although there are plenty of theoretical and empirical studies linking social support to physical health outcomes, few empirical studies have investigated theoretical assumptions more profoundly and, I argue, the same is true of the study of social support in the field of education. Social support has been studied from varied perspectives, such as life course theory, planned behaviour theory, role model theory and social capital theory. However, if analysed from a perspective of funds of knowledge, it would complement psychological frameworks that have been more dominant.

A recurring theme in the literature is the understanding of social support as a culturally based practice. Research on social support shows that students from non-dominant backgrounds are more likely to draw on their support networks. Students in these groups might have regular contact and communication with their EF and friends. As it is demonstrated below, empirical studies can be grouped into studies in which social support seems to achieve positive outcomes (attenuating disadvantage) and those in which social support outcomes are less visible or ineffective (accentuating disadvantage). 


\section{Methodology}

This paper is the result of document analysis. Following Green, Johnson and Adams (2006), a literature search directly linked to the research questions was undertaken using three main keywords 'extended family', 'higher education' and 'social support'. These were combined amongst them with deviations of the subsequent keywords: grandparents, aunts, uncles, siblings, family networks, significant others and ethnicity. Specific keywords for HE included: traditional and non-traditional students; international students; access, participation, retention, graduation and dropout. The inclusion criteria were that studies were: a) reported in English; b) published in peer-reviewed journals, as an indication of quality; and c) provided original and relevant findings relating to the research questions. This included articles, books and reports, but excluded working papers, monographs and theses. Empirical studies focusing solely on parental involvement in $\mathrm{HE}$ as well as those which focused on more extensive networks of social support in either primary and secondary education were excluded from the sample. The concepts comprising the theoretical framework of this literature review were useful tools when applying the inclusion/exclusion criteria by selecting studies which have explicitly or implicitly incorporated these conceptualisations in their analyses.

A first step was to search online bibliographic databases (Education Resources Information Centre; Social Sciences Citation Index and Web of Science). The search strategy consisted on reading the abstracts and whenever relevant sources were found full contents were assessed. A second step was to undertake citation searches using the reference lists from key articles. The search was from 2000 through 2017 and was not limited to a particular context but included experiences in a variety of countries. Fifty-three articles were considered. Selected articles (22) were then classified, synthesised and analysed by the author. 


\section{Data Analysis}

Analysis and classification were based on my own interpretation of the articles' aims, theories, methods and findings. This is considered a limitation in systematic reviews where joint reviewing is necessary (Evans and Benefield, 2001) but, in narrative reviews, judgement and interpretation (Hammersley, 2001) are essential regardless of the number of authors involved. An annotated bibliography was produced for each of the articles selected, this information was later transferred onto different tables. One table showed the different methodologies employed in the studies and another table showed the common themes found across the literature, for example, the positive effects of EF in education; the unclear separation between the support provided by parents and that provided by EF members; social support attenuating or accentuating disadvantage and the focus on specific target groups. This information was then used to create four final tables (shown in the next section) that group the literature according to different types of students: traditional; non-traditional; international and dropout.

The theoretical basis for these classifications was driven by the concepts of extended family, funds of knowledge and social support that were present either implicitly or explicitly in the literature. Although being somehow unrelated and under-investigated in the field of $\mathrm{HE}$, these concepts were chosen because they offer a solid basis for the analysis of literature looking at EF support in HE because of the following reasons. First, the support, or lack of it, that EF members provide can have an impact both at the individual level (enhancing or affecting students' well-being). However, if actively encouraged by institutions, it can also achieve wider social impact by positively contributing to widen access and completion rates at university. Second, the notion of funds of knowledge challenges established perceptions of deficit (Moll et al., 1992; Rios-Aguilar and Kiyama, 2017) amongst students from ethnic minorities and low socio-economic backgrounds who traditionally have not had a dominant 
place in HE. Third, the notion of social support expands the research scope by including the perceptions of the providers of social support (in our case EF members of HE students) by acknowledging that the outcomes of their support may be either positive, negative or neutral (in other words, accentuating or attenuating disadvantage). It is under these premises that the academic literature is now presented in the following section.

\section{Application to Higher Education}

In recent years, the study of EF support in HE has increased. Almost a third of the articles in this group (7/22) have labelled EF support generally as 'environmental factors' considering it as one variable amongst many others rather than an element worthy of analysis in its own right, assumption challenged in this paper. Qualitative methodologies predominate in this group, yet only three of twenty-two studies employed mixed-methods. The literature is grouped into four main subcategories: traditional students (18-24 year-olds); non-traditional students (25+); international students; and students who drop out.

\section{Traditional Students}

The study of EF in HE, although generally peripheral, has yielded consistent findings in relation to the importance of EF support for traditional students. This category is comprised of twelve studies. The majority of studies within this section show that EF support for traditional HE students achieves positive outcomes especially regarding students' learning approaches, academic responsibilities, choice and attainment. However, other studies within this category show that EF support outcomes for traditional HE students are less effective, for example, with respect to fighting discrimination and accessing quality HE (thus accentuating disadvantage). Studies within this group demonstrate that scholars' inclusion or exclusion of the notion of funds of knowledge is crucial in determining the outcome of support in their

Table 1 near here please 


\section{Non-traditional Students}

There is a wealth of literature focusing on HE non-traditional students' access and retention, and the institutional support available to them (Wardley, Bélanger and Leonard, 2013). In HE literature, non-traditional students are considered to be aged 25 years or older (Wyatt, 2011) with other responsibilities such as family and professional commitments. This category is comprised of three studies and although all of them demonstrate that support networks are important for non-traditional students, their results show mixed effects.

Table 2 near here please

\section{Students}

It is perhaps within the group of international students that social support has been investigated most directly, because of their social isolation from both fellow domestic students and their own networks back home. Despite the fact that they face both social and academic challenges, research shows that these do not necessarily affect completion rates (Curtin, Stewart and Ostrove, 2013), suggesting that they might draw on various types of social support to overcome social isolation and academic problems related to adjustment.

This category is comprised of five studies and all show that social support achieves positive outcomes for international students. An interesting element within this category is the variety of the support provided which does not only come from EF members in the students' country of origin but from peers, online platforms and mentoring programmes

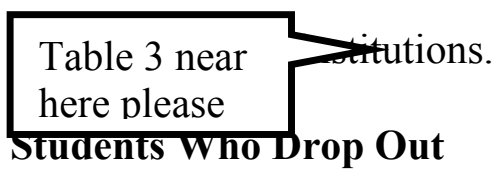

As Barefoot (2004) notes, most research on dropout from HE has focused mainly on student characteristics and the impact of 'external environments'. Very little has been said about the role of EF on the phenomenon of dropout. Hence, this category is comprised only of two studies. Both studies show that social support is crucial especially during the first

Table 4 near vin order to attenuate drop out.

here please 


\section{Discussion}

From the analysis of the literature, four main constants were observed. First, the literature is almost entirely optimistic about the positive effects of EF in education. Second, there seems to be an unclear separation between the support within HE provided by parents and that provided by EF members. Third, the reviewed studies support the view that social support in HE is a culturally based practice that can either attenuate or accentuate disadvantage. Fourth, the literature tends to focus on specific target groups: families from disadvantaged contexts and ethnic minority groups. This section makes recommendations addressed to the scholars interested in expanding research on the topic whereas the conclusions in the next section are addressed to HE practitioners and policy makers.

\section{Emphasis on Positive Effects}

In order to answer the first research question, this literature review shows that EF support may attenuate disadvantage, enable participation and progression in HE in some groups, yet it may also accentuate embedded perceptions, fail to act against discrimination or impede access (Heath, Fuller and Johnston, 2009; Juang, Ittel, Hoferichter and Gallarin, 2016; Sahu, Jeffery and Nakkeeran, 2016). However, the majority of studies tend to focus on the positive aspects of social support, namely, those that attenuate disadvantage. Therefore, in future research, the inclusion of both positive and negative effects of EF should be considered. In addition, the majority of studies collect data only from the receivers of social support (students) and fail to take into account the perceptions of the providers of such support (EF members). Amongst the reviewed literature on HE, only four studies included in their sample EF members (Heath et al., 2009; Kiyama, 2010; Khambhaita, 2014; Mwangi, 2017) whereas the rest focused on the perceptions of students alone. Therefore, future research should incorporate data from both receivers and givers of social support. 


\section{Unclear Separation between Parental Support and Support from EF}

Many studies fail to demonstrate what they understand by family support both theoretically and empirically. In these cases, there often appears to be an unclear separation between support from parents and that from EF members (Ang and Liamputtong, 2008; Juang et al., 2016; Morosanu, Handley and O’Donovan, 2010; Lee and Padilla, 2016). A metasynthesis of qualitative studies on family and community in HE (Mwangi, 2015) supports the view that definitions of family involvement in HE are still limited. In future, research using terms such as family network, relatives and close others should include a wider range of EF members in their samples rather than only nuclear family members.

\section{Social Support as a Cultural-based Practice}

In order to answer the second research question, this literature review shows that social support is a culturally based practice that varies according to place and ethnicity (Andrade, 2013; Ang and Liamputtong, 2008; Bang, Muriuki and Hodges, 2008; Khambhaita, 2014; Lee and Padilla, 2016; Palmer, Davis and Maramba, 2011; Román, Cuestas and Fenollar, 2008; Sahu et al., 2016). Research suggests that although some individuals from nondominant backgrounds might be living in more challenging environments, their social cohesion might help them to attenuate disadvantage. For example, both Andrade (2013) and Lee and Padilla (2016) show that in Amerindian and Asian cultures students value education to honouring their family. Research also shows that particularly in collectivistic societies families are an important source of financial, emotional and practical support (Ang and Liamputtong, 2008; Lee and Padilla, 2016). Therefore, the inclusion of a broader spectrum of socio-cultural backgrounds in the study of EF support in HE will help to shed light on the cultural differences of social support.

\section{Emphasis on Ethnic Minorities}

It was observed that studies have focused mainly on ethnic minority groups. Only five of 
twenty-two studies reviewed on HE included White working-class populations (Heath et al., 2009; Lent et al., 2002; Nelson, 2016; Strom and Savage, 2014, and Wilcox, Winn and Fyvie-Gauld, 2005). Therefore, young people from various socio-economic and cultural backgrounds, genders, ethnicities and age groups (including non-traditional students) need to be included in order to contribute to a conceptual understanding of how EF works across different contexts, including dominant social groups, in matters of students' access, progression and completion of HE.

\section{Experiences of social support amongst different university students}

In order to answer the third research question, this literature review shows that SS varies across the four student-types of HE students here analysed (traditional, non-traditional, international and students who drop out). Research shows that for the majority of traditional and international students the cultural aspects of family ties are important. Generally, traditional and international students who receive social support are able to translate support into educational attainment. Unlike dropout students, traditional and international students tend to attribute their academic success to their EF members. However, across all four student-types the outcomes of support are mixed, ranging from support that attenuates disadvantage to support that accentuates it. It is also worth noting that the majority of studies have been undertaken more amongst traditional than international students. Therefore, future research on EF support in HE should focus on non-traditional and students who drop out.

\section{Conclusions}

The previous sections provided a map of research on the influence of EF members in HE. The aim of this section is to link this research to HE practitioners and policy makers as a way to promote diversity within universities. In order to answer the fourth research question, the following suggestions are changes that HEIs could be making to take advantage of what is known about social support networks in HE. 
As Rios-Aguilar and Kiyama (2017) claim, the notion of funds of knowledge challenges perceptions of deficit attributed to under-represented university students. According to them, the actions of faculty and administrators are determined by their own perceptions of HE students (Rios-Aguilar and Kiyama, 2017). For this reason, policies on access and inclusion in HE should be established from a non-deficit approach that welcomes students' diverse support networks. More specifically, HEIs should include prospective students' support networks in their recruitment and widening participation activities by welcoming and listening to them. Once students are enrolled, universities should diversify their schemes of student support. This could be done through allowing diverse ways of communication that include students' own support networks outside university, and inside university, organise buddy schemes, peer mentoring and online platforms in addition to traditional counselling and enabling services already provided. In order to ease adaptation to university life it is also important that academic staff incorporate students' funds of knowledge in their pedagogical practices and curriculum as advocated by Rios-Aguilar, Kiyama, Gravitt and Moll (2011). These initiatives could help to increase recruitment amongst non-dominant groups and achieve a smother adaptation to university life for a diverse range of students. A diversified choice of resources of support at university could also help to mitigate cases where research shows that students' own sources of social support are less effective (Lent et al., 2002; Juang et al., 2016; Lee and Padilla, 2016; Sahu et al., 2016).

Some of the studies here analysed are clear examples of the implicit understanding of the notion of funds of knowledge amongst the literature. As suggested by Palmer et al. (2011), tutors and educational authorities should recognise that especially across non-dominant backgrounds, diverse family members are well equipped at encouraging and supporting students' participation and completion in HE. Similarly, both Ang and Liamputtong (2008) and Morosanu et al. (2010) show that, in many cases, families are students' main source of 
support in addition to the support resources provided at university.

There are continual calls in the literature for further research on social support in education generally (Hardgrove, McDowell and Rootham, 2015; Pallock and Lamborn, 2006; Richardson, 2009; Salami, 2008). However, as this literature review demonstrates, there is a growing number of studies on social support in HE.

The limitations of this literature review are the restricted number of studies analysed, the exclusion of potential valuable papers published in languages other than English, and the difficulty in comparing research outcomes from studies employing diverse analytical lenses and methods. This was challenging, given the diverse nature of the selected papers, which varied enormously in terms of focus, perspectives, methodologies, conceptual frameworks and findings. Whenever possible, similarities and differences between studies were highlighted, as well as their particular contributions in relation to the literature review's research questions.

The originality of this literature review resides on three aspects. First, the integration of multidisciplinary knowledge. This will help to advance our understanding on the cultural differences of EF support in HE in order to provide direction for HE practitioners to better support students. Second, the distinction between social support attenuating and accentuating disadvantage is an element that has been generally underdeveloped including in the literature of funds of knowledge. Finally, the consideration of both dominant and non-dominant social backgrounds across a variety of ethnic groups which provides a comprehensive understanding of the different ways in which students studying in diverse HE systems draw on social support.

As research evidence shows (Bang et al., 2008; Menzies, Baron and Zutshi, 2015; Palmer et al., 2011; Sullivan and Kashubeck-West, 2015), a better understanding of EF support can help educational institutions globally to tailor schemes of support to their student 
population according to the support they receive or fail to receive from their support networks outside of university. It can also clarify the extent to which EF support meets students' educational and occupational aspirations - or not. 


\section{Acknowledgements}

I would like to express my sincere thanks to Joanna Apps, Tony Kelly, Jon P.

Knudsen, Bruce Macfarlane and Melanie Nind for comments on earlier drafts as well as the anonymous reviewers who identified areas of my manuscript that needed modification.

\section{References}

Andrade, M. S. (2013). I can do everything: Family influence on American Indian Women's educational aspirations. Journal of American Indian Education, 3-25.

Ang, P. L., and Liamputtong, P. (2008). 'Out of the circle': International students and the use of university counselling services. Australian Journal of Adult Learning, 48(1), 108.

Baars, S., Mulcahy, E., and Bernardes, E. (2016). The underrepresentation of white working class boys in higher education: The role of widening participation. Kings College London.

Bang, E.-J., Muriuki, A., and Hodges, J. Q. (2008). International Students at a Midwestern University: Gender, Stress, and Perceived Social Support. International Journal of Diversity in Organisations, Communities and Nations, 8(4).

Barefoot, B. (2004). Higher education's revolving door: Confronting the problem of student drop out in US colleges and universities. Open Learning: The Journal of Open, Distance and e-Learning, 19(1), 9-18.

Basit, T., and Tomlinson, S. (Eds.). (2012). Social inclusion and higher education. Bristol: Policy.

Boliver, V. (2013). How fair is access to more prestigious UK universities? British Journal of Sociology, 64(2), 344-364.

Briggs, A. R. J., Clark, J., and Hall, I. (2012). Building bridges: Understanding student transition to university. Quality in Higher Education, 18(1), 3-21.

Broad, B. (2004). Kinship care for children in the UK: Messages from research, lessons for 
policy and practice. European Journal of Social Work, 7(2), 211-227.

Brooks, R. (2005). Friendship and educational choice: Peer influence and planning for the future. Basingstoke: Palgrave Macmillan.

Carney-Crompton, S., and Tan, J. (2002). Support systems, psychological functioning, and academic performance of nontraditional female students. Adult Education Quarterly, $52(2), 140-154$.

Chen, L., and Yang, X. (2015). Nature and effectiveness of online social support for intercultural adaptation of Mainland Chinese international students. International Journal of Communication, 9, 21.

Cox, D., and Fafchamps, M. (2007). Extended family and kinship networks: Economic insights and evolutionary directions. Handbook of development economics, 4, 37113784.

Croxford, L., and Raffe, D. (2014). Social class, ethnicity and access to higher education in the four countries of the UK: 1996-2010. International Journal of Lifelong Education, $33(1), 77-95$.

Curtin, N., Stewart, A. J., and Ostrove, J. M. (2013). Fostering academic self-concept: Advisor support and sense of belonging among international and domestic graduate students. American Educational Research Journal, 50(1), 108-137.

Duranton, G., Rodríguez-Pose, A., and Sandall, R. (2009). Family types and the persistence of regional disparities in Europe. Economic Geography, 85(1), 23-47.

Evans, J., and Benefield, P. (2001). Systematic Reviews of Educational Research: Does the medical model fit? British Educational Research Journal, 27(5), 527-541.

Gates, P., Coward, S., and Byrom, T. (2007). Young participation in higher education in the parliamentary constituency of Nottingham North (pp. 1-14). Nottingham: University of Nottingham. 
Gofen, A. (2009). Family capital: How first-generation higher education students break the intergenerational cycle. Family Relations, 58(1), 104-120.

Green, B. N., Johnson, C. D. and Adams, A. (2006). Writing narrative literature reviews for peer-reviewed journals: secrets of the trade. Journal of chiropractic medicine, 5(3), 101-117.

Grundy, E., Murphy, M., and Shelton, N. (1999). Looking beyond the household: Intergenerational perspectives on living kin and contacts with kin in Great Britain Population Trends (vol. 97, pp. 19-27). London: Office for National Statistics.

Hammersley, M. (2001). On 'Systematic' Reviews of Research Literatures: A 'narrative' response to Evans and Benefield. British Educational Research Journal, 27(5), 543554.

Hardgrove, A., McDowell, L., and Rootham, E. (2015). Precarious lives, precarious labour: Family support and young men's transitions to work in the UK. Journal of Youth Studies, 18(8), 1057-1076.

Heath, S., Fuller, A., and Johnston, B. (2009). Chasing shadows: Defining network boundaries in qualitative social network analysis. Qualitative Research, 9(5), 645-661.

Heath, S., Fuller, A., and Johnston, B. (2010). Young people, social capital and network-based educational decision-making. British Journal of Sociology of Education, 31(4), 395-411.

Hrdy, S. (2009). Mothers and others: The evolutionary origins of mutual understanding. Cambridge, MA: Harvard University Press.

Juang, L., Ittel, A., Hoferichter, F., and Gallarin, M. M. (2016). Perceived racial/ethnic discrimination and adjustment among ethnically diverse college students: Family and peer support as protective factors. Journal of College Student Development, 57(4), 380394. 
Khambhaita, P. (2014). Indian mothers' perceptions of their roles in their daughters' university course choices. British Educational Research Journal, 40(6), 1019-1035.

Kiyama, J. M. (2010). College Aspirations and Limitations: The Role of Educational Ideologies and Funds of Knowledge in Mexican American Families. American Educational Research Journal, 47(2), 330-356.

Lasselle, L., Keir, F., and Smith, I. (2009). Enhancing pupils' aspirations to university: The St Andrews Sutton Trust School experience. Journal of Further and Higher Education, 33(4), 395-410.

Lee, D. S., and Padilla, A. M. (2016). Predicting South Korean university students' happiness through social support and efficacy beliefs. International Journal for the Advancement of Counselling, 38(1), 48-60.

Lent, R. W., Brown, S. D., Talleyrand, R., McPartland, E. B., Davis, T., Chopra, S. B., and Chai, C. (2002). Career choice barriers, supports, and coping strategies: College students' experiences. Journal of Vocational Behavior, 60(1), 61-72.

MacDonald, C., and Stratta, E. (2001). From access to widening participation: Responses to the changing population in higher education in the UK. Journal of Further and Higher Education, 25(2), 249-258.

McGlone, F., Park, A., and Roberts, C. (1999). Kinship and friendship: Attitudes and behaviour in Britain, 1986-1995. In S. McRae (Ed.), Changing Britain. Families and Households in the 1990s (pp. 141-155). Oxford: Oxford University Press.

McRae, S. (1999). Introduction: family and household change in Britain. In S. McRae (Ed.), Changing Britain: Families and Households in the 1990s (pp. 1-33). Oxford: Oxford University Press.

Menzies, J. L., Baron, R., and Zutshi, A. (2015). Transitional experiences of international postgraduate students utilising a peer mentor programme. Educational Research, 57(4), 
403-419.

Mitchell, W. (2007). Research review: The role of grandparents in intergenerational support for families with disabled children: a review of the literature. Child and Family Social Work, 12(1), 94-101.

Moll, L., Amanti, C., Neff, D., and Gonzalez, N. (1992). Funds of Knowledge for Teaching: Using a Qualitative Approach to Connect Homes and Classrooms. Theory Intro Practice, 31(2), 132-141.

Morosanu, L., Handley, K., and O’Donovan, B. (2010). Seeking support: researching first-year students' experiences of coping with academic life. Higher Education Research and Development, 29(6), 665-678.

Mwangi, C. A. G. (2015). (Re)Examining the role of family and community in college access and choice: A metasynthesis. The Review of Higher Education, 39(1), 123-151. The Johns Hopkins University Press.

Mwangi, C. A. G. (2017). A Family Affair: Examining College-Going Among Sub-Saharan African Immigrants in the US Through a Funds of Knowledge Lens. In Kiyama, J. M. and Rios-Aguilar, C. (Eds.). Funds of knowledge in higher education: Honoring students' cultural experiences and resources as strengths (pp. 106-124). New York: Routledge.

Nelson, I. A. (2016). Rural Students' Social Capital in the College Search and Application Process. Rural Sociology, 81(2), 249-281.

Pallock, L. L., and Lamborn, S. D. (2006). Beyond parenting practices: Extended kinship support and the academic adjustment of African-American and European-American teens. Journal of Adolescence, 29(5), 813-828.

Palmer, R. T., Davis, R. J. and Maramba, D. C. (2011). The Impact of Family Support on the Success of Black Men at an Historically Black University: Affirming the Revision of 
Tinto’s Theory. Journal of College Student Development, 52(5), 577-597.

Reay, D., Crozier, G., and Clayton, J. (2009). 'Strangers in paradise'? Sociology, 43(6), 1103 1121.

Reay, D., David, M., and Ball, S. (2005). Degrees of choice: Class, race, gender and higher education. Stoke-on-Trent: Trentham.

Richardson, J. B. (2009). Men do matter. Journal of Family Issues, 30(8), 1041-1069.

Rios-Aguilar, C., Kiyama, J. M., Gravitt, M., and Moll, L. C. (2011). Funds of knowledge for the poor and forms of capital for the rich? A capital approach to examining funds of knowledge. Theory and Research in Education, 9(2), 163-184.

Rios-Aguilar, C. and Kiyama, J. M. (2017). The need for a funds of knowledge approach in higher education contexts. In Kiyama, J. M. and Rios-Aguilar, C. (Eds.). Funds of knowledge in higher education: Honoring students' cultural experiences and resources as strengths (pp. 3-7). New York: Routledge.

Román, S., Cuestas, P. J., and Fenollar, P. (2008). An examination of the interrelationships between self-esteem, others' expectations, family support, learning approaches and academic achievement. Studies in Higher Education, 33(2), 127-138.

Sahu, B., Jeffery, P., and Nakkeeran, N. (2016). Barriers to higher education: Commonalities and contrasts in the experiences of Hindu and Muslim young women in urban Bengaluru. Compare: A Journal of Comparative and International Education, available online at http://dx.doi.org/10.1080/03057925.2016.1220825.

Salami, S. (2008). Roles of personality, vocational interests, academic achievement and socio-cultural factors in educational aspirations of secondary school adolescents in southwestern Nigeria. Career Development International, 13(7), 630-647.

Schwarzer, R., and Leppin. A. (1991). Social support and health: A theoretical and empirical overview. Journal of Social and Personal Relationships, 8(1), 99-127. 
Shumaker, S. A., and Brownell, A. (1984). Toward a theory of social support: Closing conceptual gaps. Journal of Social Issues, 40(4), 11-36.

Strom, R. E., and Savage, M. W. (2014). Assessing the relationships between perceived support from close others, goal commitment, and persistence decisions at the college level. Journal of College Student Development, 55(6), 531-547.

Sullivan, C., and Kashubeck-West, S. (2015). The interplay of international students' acculturative stress, social support, and acculturation modes. Journal of International Students, 5(1), 1-11.

Wardley, L. J., Bélanger, C. H., and Leonard, V. M. (2013). Institutional commitment of traditional and non-traditional-aged students: A potential brand measurement? Journal of Marketing for Higher Education, 23(1), 90-112.

Watt, S. M., and Paterson, L. (1997). Mind the gap! School to higher education: Still bridging the gap five years on. Journal of Further and Higher Education, 21(3), 317-324.

Wilcox, P., Winn, S., and Fyvie-Gauld, M. (2005). 'It was nothing to do with the university, it was just the people': The role of social support in the first-year experience of higher education. Studies in Higher Education, 30(6), 707-722.

Wyatt, L. G. (2011). Nontraditional student engagement: Increasing adult student success and retention. Journal of Continuing Higher Education, 59(1), 10-20.

Young, M., and Willmott, P. (1957). Family and kinship in East London. London: Routledge and Kegan Paul. 
Table 1 Traditional-aged students

\begin{tabular}{|c|c|c|c|c|c|c|c|}
\hline & Author/s & Year & Participants & Context & $\begin{array}{l}\text { Data collection } \\
\text { methods }\end{array}$ & Main findings & Outcome of support \\
\hline 1. & Román, Cuestas and Fenollar & 2008 & 553 UG students & Spain & Questionnaires & $\begin{array}{l}\text { Support from EF has positive effects } \\
\text { on students learning. Cultural aspects } \\
\text { of family ties are important. }\end{array}$ & \multirow{8}{*}{$\begin{array}{l}\text { EF support achieves positive } \\
\text { outcomes. The socio-economic } \\
\text { and cultural background of EF } \\
\text { members does not determine the } \\
\text { extent and quality of their } \\
\text { support. }\end{array}$} \\
\hline 2. & Gofen & 2009 & $\begin{array}{l}50 \text { UG first-generation } \\
\text { students }\end{array}$ & Israel & $\begin{array}{l}\text { Semi-structured } \\
\text { interviews }\end{array}$ & $\begin{array}{l}\text { Students attribute their success to their } \\
\text { EF members. }\end{array}$ & \\
\hline 3. & Kiyama & 2010 & $\begin{array}{l}27 \text { Hispanic families } \\
\text { attending an Outreach } \\
\text { Programme }\end{array}$ & U.S.A. & $\begin{array}{l}\text { Semi-structured } \\
\text { interviews }\end{array}$ & $\begin{array}{l}\text { Families place a high value in } \\
\text { education. Their knowledge about } \\
\text { choice and preparation for HE is } \\
\text { constructed in non-traditional ways } \\
\text { but is often incomplete. The Outreach } \\
\text { Programme gives families concrete } \\
\text { and realistic information about HE. }\end{array}$ & \\
\hline 4. & $\begin{array}{l}\text { Morosanu, Handley and } \\
\text { O'Donovan }\end{array}$ & 2010 & 5 first-year students & England & Audio diaries & $\begin{array}{l}\text { Students do not always embrace } \\
\text { institutional support and informal } \\
\text { networks help them to cope with their } \\
\text { academic responsibilities. }\end{array}$ & \\
\hline 5. & Palmer, Davis and Maramba & 2011 & $\begin{array}{c}11 \text { Black male UG } \\
\text { students }\end{array}$ & U.S.A. & $\begin{array}{l}\text { Face-to-face and } \\
\text { follow-up interviews }\end{array}$ & $\begin{array}{l}\text { Support from parents, siblings and EF } \\
\text { impacts students' ability to succeed in } \\
\text { their courses. }\end{array}$ & \\
\hline 6. & Khambhaita & 2014 & 9 Indian mothers & England & $\begin{array}{l}\text { Semi-structured } \\
\text { interviews }\end{array}$ & $\begin{array}{l}\text { Working- and middle-class Indian } \\
\text { mothers use EF members as a source } \\
\text { of knowledge to support their } \\
\text { daughters' university course choices. }\end{array}$ & \\
\hline 7. & Nelson & 2016 & $\begin{array}{l}30 \text { predominately } \\
\text { White graduates }\end{array}$ & U.S.A. & $\begin{array}{l}\text { Semi-structured } \\
\text { interviews }\end{array}$ & $\begin{array}{l}\text { Family, school and community capital } \\
\text { influence financially disadvantaged } \\
\text { but academically successful rural } \\
\text { students during their university search } \\
\text { and application process. Students are } \\
\text { able to translate support into } \\
\text { educational attainment. }\end{array}$ & \\
\hline 8. & Mwangi & 2017 & $\begin{array}{l}9 \text { Black sub-Saharan } \\
\text { African families }\end{array}$ & U.S.A. & $\begin{array}{l}\text { Ethnographic multi- } \\
\text { case study }\end{array}$ & $\begin{array}{l}\text { Motivation for HE is part of a larger } \\
\text { family effort towards upward } \\
\text { mobility. Families pass the value of } \\
\text { education on to their first-generation } \\
\text { offspring. }\end{array}$ & \\
\hline 9. & $\begin{array}{l}\text { Lent, Brown, Talleyrand, } \\
\text { McPartland, Davis, Chopra and } \\
\text { Chai }\end{array}$ & 2002 & $\begin{array}{l}31 \mathrm{UG} \text { and graduate } \\
\text { students }\end{array}$ & U.S.A. & Structured interviews & $\begin{array}{l}\text { Although participants cite social } \\
\text { support as a critical factor in career } \\
\text { choice, students' perception of } \\
\text { support and barriers is likely to be } \\
\text { affected by their socio-economic } \\
\text { status, level of education and culture. }\end{array}$ & \multirow[t]{2}{*}{$\begin{array}{l}\text { EF support outcomes are less } \\
\text { effective. The socio-economic } \\
\text { background of EF members } \\
\text { determine the extent and quality } \\
\text { of their support. }\end{array}$} \\
\hline 10. & $\begin{array}{l}\text { Juang, Ittel, Hoferichter and } \\
\text { Gallarin }\end{array}$ & 2016 & $\begin{array}{l}142 \text { ethnically diverse } \\
\text { students }\end{array}$ & U.S.A. & Self-report survey & $\begin{array}{l}\text { Family support is inefficient to disable } \\
\text { peer discrimination due to their lack }\end{array}$ & \\
\hline
\end{tabular}




\begin{tabular}{|c|c|c|c|c|c|c|c|}
\hline & & & & & & $\begin{array}{l}\text { of proximity and understanding of } \\
\text { university life. }\end{array}$ & \\
\hline 11. & Lee and Padilla & 2016 & $\begin{array}{l}198 \text { predominately } \\
\text { high-achieving } \\
\text { students }\end{array}$ & South Korea & Questionnaire & $\begin{array}{l}\text { Students' perception of social support } \\
\text { is a predictor of happiness, especially } \\
\text { within their close social circles. } \\
\text { However, students rely on themselves } \\
\text { in times of adversity, decreasing the } \\
\text { potential for social support during } \\
\text { stressful events. }\end{array}$ & \\
\hline 12. & Sahu, Jeffery and Nakkeeran & 2016 & $\begin{array}{l}26 \text { university } \\
\text { applicants }\end{array}$ & India & In-depth interviews & $\begin{array}{l}\text { Social control from EF in India acts as } \\
\text { a barrier to accessing quality HE. EF } \\
\text { members tend to influence parents not } \\
\text { to send their daughters to university } \\
\text { and interfere with or discourage } \\
\text { certain career choices considered } \\
\text { male-dominated fields. }\end{array}$ & \\
\hline
\end{tabular}

Table 2 Non-traditional students

\begin{tabular}{|c|c|c|c|c|c|c|c|}
\hline & Author/s & Year & Participants & Context & $\begin{array}{c}\text { Data collection } \\
\text { methods }\end{array}$ & Main findings & Outcome of support \\
\hline 1. & Carney-Crompton and Tan & 2002 & $\begin{array}{c}63 \text { female university } \\
\text { students }\end{array}$ & Canada & Survey & $\begin{array}{l}\text { Non-traditional students perform at a } \\
\text { higher level than traditional students, } \\
\text { despite having fewer sources of } \\
\text { emotional and instrumental support. }\end{array}$ & \multirow{3}{*}{$\begin{array}{l}\text { Although support networks ar } \\
\text { important for non-traditional } \\
\text { students, their effect does not } \\
\text { guarantee achieving positive } \\
\text { educational outcomes. }\end{array}$} \\
\hline 2. & Heath, Fuller and Johnston & $\begin{array}{l}2009 ; \\
2010\end{array}$ & 107 adults & England & $\begin{array}{l}\text { Qualitative social } \\
\text { network } \\
\text { analysis }\end{array}$ & $\begin{array}{l}\text { Although educational decision- } \\
\text { making is a network-embedded } \\
\text { process, first-hand experience of HE } \\
\text { does not necessarily add bridging } \\
\text { capital to a network, and can } \\
\text { sometimes even act as a } \\
\text { reinforcement of existing network } \\
\text { perceptions of non-participation in } \\
\text { HE. }\end{array}$ & \\
\hline 3. & Andrade & 2013 & $\begin{array}{l}18 \text { American Indian } \\
\text { graduate women }\end{array}$ & U.S.A. & Online survey & $\begin{array}{l}\text { Familial role is critical to non- } \\
\text { traditional students' HE dispositions. } \\
\text { Family members encourage } \\
\text { participants to pursue university } \\
\text { admission and, when possible, help } \\
\text { with university life. }\end{array}$ & \\
\hline
\end{tabular}


Table 3 International students

\begin{tabular}{|c|c|c|c|c|c|c|c|}
\hline & Author/s & Year & Participants & Context & $\begin{array}{c}\text { Data collection } \\
\text { methods }\end{array}$ & Main findings & Outcome of support \\
\hline 1. & Ang and Liamputtong & 2008 & $\begin{array}{l}7 \text { UG and graduate } \\
\text { Chinese students }\end{array}$ & Australia & In-depth interviews & $\begin{array}{l}\text { Families are students' main source of } \\
\text { support, which reduces their need to } \\
\text { speak to university counsellors in a } \\
\text { language other than their own. }\end{array}$ & \multirow[t]{5}{*}{$\begin{array}{l}\text { Support networks at home and on- } \\
\text { campus help international students } \\
\text { to cope with studying abroad. }\end{array}$} \\
\hline 2. & Bang, Muriuki and Hodges & 2008 & $\begin{array}{l}291 \text { international } \\
\text { students }\end{array}$ & U.S.A. & Online survey & $\begin{array}{l}\text { Significant gender differences found } \\
\text { between female and male } \\
\text { international students. Female } \\
\text { international students have better } \\
\text { social support networks and seek } \\
\text { more help than male counterparts. }\end{array}$ & \\
\hline 3. & Chen and Yang & 2015 & $\begin{array}{c}21 \text { Chinese } \\
\text { international students }\end{array}$ & Singapore & $\begin{array}{l}\text { In-depth interviews } \\
\text { and qualitative content } \\
\text { analysis of } 1736 \\
\text { posted messages }\end{array}$ & $\begin{array}{l}\text { Students are able to both seek and } \\
\text { provide informational, instrumental, } \\
\text { emotional and network support } \\
\text { amongst them through online } \\
\text { platforms. }\end{array}$ & \\
\hline 4. & Menzies, Baron and Zutshi & 2015 & $\begin{array}{c}31 \text { postgraduate } \\
\text { international students }\end{array}$ & Australia & $\begin{array}{l}\text { Semi-structured } \\
\text { interviews }\end{array}$ & $\begin{array}{l}\text { Social support can be effectively } \\
\text { provided through a university-based } \\
\text { peer-mentoring programme to } \\
\text { facilitate transition to HE. }\end{array}$ & \\
\hline 5. & Sullivan and Kashubeck-West & 2015 & $\begin{array}{l}104 \text { international } \\
\text { students }\end{array}$ & U.S.A. & Online survey & $\begin{array}{l}\text { Students with broad-based social } \\
\text { support experience lower levels of } \\
\text { acculturative stress. Maintaining } \\
\text { connection to the home culture and } \\
\text { developing positive connections to } \\
\text { the host culture, co-national and other } \\
\text { international students, helps to } \\
\text { increase cultural adaptation in HE. }\end{array}$ & \\
\hline
\end{tabular}

Table 4 Dropout students

\begin{tabular}{|c|l|c|c|c|c|c|}
\hline & \multicolumn{1}{|c|}{ Author/s } & Year & Participants & Context & $\begin{array}{c}\text { Data collection } \\
\text { methods }\end{array}$ & Matcome of support \\
\hline 1. & Wilcox, Winn, and Fyvie-Gauld & 2005 & 34 students & England & $\begin{array}{l}\text { Interviews } \\
\text { The majority of students who dropout } \\
\text { social support is one. Failing to make } \\
\text { friends at university is crucial to the } \\
\text { decision on whether to stay or drop } \\
\text { out. }\end{array}$ & $\begin{array}{l}\text { Social support is crucial especially } \\
\text { during the first years at university } \\
\text { in order to attenuate drop out. }\end{array}$ \\
\hline 2. & Strom and Savage & 2014 & $\begin{array}{c}101 \text { first-year } \\
\text { ethnically diverse } \\
\text { students }\end{array}$ & U.S.A & Questionnaires & $\begin{array}{l}\text { Initial support provided by 'close } \\
\text { others' has a significant impact on } \\
\text { students' initial commitment to the } \\
\text { goal of graduation. }\end{array}$ \\
\hline
\end{tabular}

